I. Kahoul $^{1}$,
S. Yahyaoui $^{2}$,
Y. Mehidi $^{3}$,
Y. Khadri $^{1}$

\title{
SHALLOW TUNNEL FACE STABILITY ANALYSIS USING FINITE ELEMENTS
}

Purpose. This work aims to study the tunnel face stability (Algiers subway Tunnel) and evaluate common numerical procedures that are used for analyzing the tunnel face stability. Two-dimensional (2D) and three-dimensional (3D) Finite Element (FE) modeling using PLAXIS programs.

Methodology. Tunneling is executed by the NATM method; two types of calculations are used. The first one is done by reducing the applied face pressure until the face is collapsed. The second calculation method involves the Phi-c (the angle of internal friction and bonding) reduction method, which is based on calculating the safety factor of the shear strength of the soil. Both methods are applied for 2D and 3D FE-modelling.

Findings. It is found that determining the applied face pressure is an important consideration to avoid face failure or excessive deformations with numerical methods resulting in more precise findings than analytical methods.

Originality. The originality of this work is the use of both 2D and 3D modelling, combined with two approaches: structural analysis of plastic state and Phi-c reduction method based on calculating the safety factor of the shear strength of the soil.

Practical value. This study illustrates that the reducing shear strength method is much better than the reducing applied face pressure method. Moreover, the result of 3D FE-modelling gives a better prediction comparing with the 2D FE-modelling results.

Keywords: tunnel, numerical modelling, tunnel face stability, Plaxis 2D, Plaxis 3D tunnel, Algiers subway tunnel

Introduction. Determining the type of ground and its strength is the most important factor in any tunnel project to decide on the construction method. In soft ground, when face failure is a problem, reducing the amount of deformation in the tunneling process is the first criterion. The construction of tunnels by the Crown/Bench \& Base method is envisaged when there is a quasi-elastic behavior of the ground after the excavation; this is considered as a special case of the New Austrian tunneling Method (NATM).

To avoid face failure, the applied face pressure must be within the limits. Upper and lower limits determine the critical conditions beyond which tunnel face failure may occur; so, determining the applied face pressure is an important thing to avoid excessive deformations.

Different analytical and numerical analyses have been established to define the limits of face failure. [1] has studied the minimum required support pressure at tunnel face, using different analytical equations and numerical simulation, and as a result, it was found that numerical methods are more accurate computation techniques than analytical methods.

Although the analytical methods are easy to use and give a quick interpretation of the problem, the superiority of numerical methods cannot be ignored, especially when dealing with complex three dimensional model with different layers of soil in heterogeneity site [2].

There are different simulation procedures in numerical modeling for an accounting of how failure in the face could occur, as those simulations have differences in failure mode, and they might give different safety factors concerning face failure [3].

This paper focuses on the determination of the lower limit for face stability by applying two different numerical procedures. Those procedures were applied in 2D and 3D Finite Element modelling (FE-modelling) to determine the minimum required support pressure and the safety factor using PLAXIS programs. The consideration is only for the calculation of the full failure of the tunnel face without taking into account the displacement-stage relationship in the simulation methods. It was found that it is very important to consider this relationship for the shear-strength reduction method because the mode of failure is obtained with a large amount of deformation. Besides, drained condition was not taken into account.

(C) Kahoul I., Yahyaoui S., Mehidi Y., Khadri Y., 2021
Theory. Many studies treated the case of materials governed by a Mohr-Coulomb criterion, from the perspective of limiting analysis.

It was possible to identify lower and upper bounds of internal pressure limit values for the case of a circular tunnel in the current section in rubbing materials. These bounds gave a satisfactory framework for the experimental results.

Zizka, et al. [4] approached the case of the stability of the tunnels dug in friction and coherent grounds. However, unlike previous authors, who were interested in the stability of a tunnel in the current section, Zizka, et al. [4] studied the case of an infinite width of mine size.

The work by Leca and Dormieux [5] made it possible to obtain upper and lower internal pressure limits for ensuring tunnel face stability. The results can be in the form

$$
\left\{\begin{array}{l}
Q_{T}=N_{s}^{+} Q_{s}+N_{\gamma}^{+} Q_{\gamma} \\
Q_{T}=N_{s}^{-} Q_{s}+N_{\gamma}^{-} Q_{\gamma}
\end{array}\right.
$$

where

$$
\begin{gathered}
Q_{s}=\left(K_{p}-1\right) \frac{\sigma_{s}}{\sigma_{c}}+1 ; \\
Q_{T}=\left(K_{p}-1\right) \frac{\sigma_{T}}{\sigma_{c}}+1 ; \\
Q_{\gamma}=\left(K_{p}-1\right) \frac{\gamma_{D}}{\sigma_{c}},
\end{gathered}
$$

where $Q_{T}$ is support stability limit; $Q_{s}$ is soil stability limit; $Q_{\gamma}$ is global stability limit according to volume weight; $\sigma_{s}$ is soil pressure; $\sigma_{T}$ is support pressure; $\gamma_{D}$ is volume weight; $\sigma_{c}$ is vertical pressure; $K_{p}$ is the stop coefficient.

The exponents + and - represent coefficients $N_{s}$ and $N_{\gamma}$ correspond respectively to the upper or lower bounds. The values of the coefficients $N_{s}$ and $N_{\gamma}$ result from the minimization of the mechanisms proposed by Leca and Dormieux [5] for the upper bound and from the stress fields for the lower bound.

The calculation of the tunnel face stability was based on the estimation of the support pressure to be exerted on tunnel face to be able to guarantee its stability. Among the methods widely applied in soft ground and considered by the MohrCoulomb type material is the Murayama method.

Murayama's method is based on the estimation of the ground pressure at the head of the tunnel and balance of the groundmass located in front of the structure. The ground pres- 
sure can be calculated in the case of tunnels with low coverage as equal to the geostatic stress [6].

The sliding surface used consists of a logarithmic spiral, whose tangent makes an angle of $\pi / 2-\varphi$ with the vector radius, $r_{\theta}$, and which develops between the lower part and the head of the tunnel (Fig. 1), the angle between the extreme radius $r_{s}$ and $r_{i}$ being equal to $\pi / 4-\varphi / 2$.

The geometric parameters of the spiral were deduced from the expression of the spiral $r_{\theta}=r_{s} \exp (\theta \tan \varphi)$. We deduce the expressions of the diameter $D$ and the depth $L_{1}$

$$
\begin{gathered}
D=r_{s}\left[\sin (\pi / 4+\varphi / 2) e^{\tan \varphi(\pi / 4-\varphi / 2)}-\sin \varphi\right] ; \\
L_{1}=r_{s} \cos \varphi-r_{i} \cos (\pi / 4+\varphi / 2) .
\end{gathered}
$$

The support pressure at the face is obtained by writing the equilibrium of the moments for the point $O$. We note that, because the tangent of the spiral makes an angle of $\pi / 2-\varphi$ with the vector radius, any force applied to the sliding surface, and making an angle $\varphi$ with it, results in a zero moment. The balance of moments is written as follows

$$
R_{\sigma_{r}} L_{\sigma_{r}}=R_{\gamma} L_{\gamma}+R_{\sigma_{c r}} L_{\sigma_{c r}}-C \frac{r_{i}^{2}-r_{s}^{2}}{2 \tan \varphi},
$$

where $L_{\sigma_{r}}, L_{\gamma}$ and $L_{\sigma_{c r}}$ refers to the lever arms of the different resultants. The resolution of equation (4) leads to an estimate of the pressure to be applied on the face. This method combines two types of two-dimensional approaches, but in two perpendicular directions.

Analytical solution. A face stability index $(N)$ is the ratio between the difference between the natural pressure and the pressure applied to the tunnel face, and the undrained shear strength to analyze tunnel face stability. The stability ratio was devised based on cohesive ground (clay) and it was found that the tunnel face would be stable when the index is less than six.

$$
N=\frac{\left(\delta_{s}+\gamma H-\delta_{t}\right)}{S_{u}},
$$

where $H$ is the depth of tunnel axis; $\delta_{s}$ is surface surcharge; $\delta_{t}$ is tunnel support pressure; $S_{u}$ is undrained shear strength at tunnel axis.

Depending on the ratio between the depth of the tunnel and its diameter $(H / D)$, the stability ratio $(N)$ is equal to between five and seven for $H / D=1.5$.

Elastic and Plastic theories were often used to obtain the tunnel radial response. In those cases, to compare analytical and numerical results, the equation (6) is used to obtain the analytical tunnel displacement [7].

$$
U=\left(\gamma H_{0}-p_{a}\right) \frac{(1+v) D}{2 E}
$$

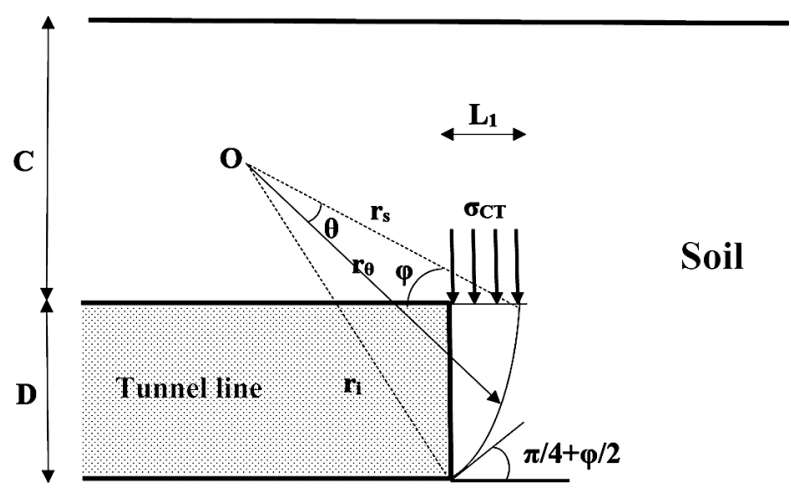

Fig. 1. Diagram of Murayama's method where $u$ is elastic displacement in the tunnel periphery; $\gamma$ is soil specific weight; $H_{o}$ is depth from the ground surface to the center of the tunnel; $p_{a}$ is soil radial stress in the tunnel periphery; $v$ is Poisson's ratio; $D$ is the tunnel diameter; $E$ is soil elastic modulus.

Moreover, the characteristic curve of the primary support of the tunnel was obtained using equation (7) [8].

$$
u_{c}=\frac{p_{a} D_{m}^{2}}{4 t E_{c}}
$$

where $u$ is elastic displacement in the tunnel periphery; $D_{m}$ is annular medium diameter of the support; $E_{c}$ is elastic modulus of the concrete.

The analytical results are represented in Table1.

According to the analytical results, the tunnel diameter is $9 \mathrm{~m}$ and the primary support should have a thickness of $0.6 \mathrm{~m}$ with concrete of $33000 \mathrm{Kpa}$ as elastic modulus.

Numerical simulations (FEM). General-purpose numerical analysis techniques, such as finite element methods, were developed in the 1960s. The numerical simulation can be used to follow the natural sequence of events involved in construction.

In this paper, a finite element program PLAXIS was used for the analysis by application of the Mohr-Coulomb model.

PLAXIS is a finite element package, especially intended for the analysis of deformation and stability in geotechnical engineering projects. Different practical methods are implemented to analyze the deformation that occurs due to the construction of the tunnel. PLAXIS works with different soil model types [9]. It is equipped with special features to deal with the numerous aspects of complex geotechnical structures. The minimum required support pressure at tunnel face was calculated by applying a support pressure at the face, which is equal to the total overburden pressure, and then it was reduced until the face collapsed.

The Mohr-Coulomb model, being a robust and simple non-linear model, is based on soil parameters that are known in most practical situations. Not all non-linear features of soil behavior are included in this model, however. The MohrCoulomb model may be used to compute realistic support pressures for tunnel faces, ultimate loads for footing, and so on. It may also be used to calculate a safety factor using a 'Phic reduction' approach.

This criterion, commonly used in soil mechanics, has the following expression (8)

$$
\begin{gathered}
f(\sigma)=\sup \left\{\sigma_{i}(1+\sin \varphi)-\sigma_{j}(1-\sin \varphi)-2 c \cos \varphi\right\}, \\
i, j=1,2,3 .
\end{gathered}
$$

In reality, the criterion used in our digital developments differs slightly from the Mohr-Coulomb criterion presented above. To fulfill the conditions of equivalence between static and cinematic approaches, it was necessary to use a criterion with maximum compression, the cohesion always being greater than zero. Smith, et al. [10] expressed it in equation (9).

$$
\begin{gathered}
f(\sigma)=\sup \left\{\sigma_{i}(1+\sin \varphi)-\sigma_{j}(1-\sin \varphi)-2 c \cos \varphi-\sigma_{i}-C\right\}, \\
i, j=1,2,3 .
\end{gathered}
$$

Digging a tunnel is a three-dimensional problem, especially in the front area. This was well demonstrated by Barla [11] based on the analysis of the stress and displacement distri-

Table 1

Structural parameters for the tunnel primary support

\begin{tabular}{|l|c|}
\hline \multicolumn{1}{|c|}{ Parameter } & value \\
\hline support thickness $t(\mathrm{~m})$ & 0.6 \\
\hline annular medium diameter of the support $D_{m}(\mathrm{~m})$ & 9 \\
\hline elastic modulus of the concrete $E(\mathrm{Kpa})$ & 33000 \\
\hline
\end{tabular}


bution as well as the pacing path of the effort around the tunnel front. Numerical modeling in three dimensions is, therefore, necessary to study this phenomenon in all its complexity. With this approach, the three-dimensional geometry of the project, the state of the initial stresses (even anisotropic), the digging method, the phasing of the works, the surface loads, and others can indeed be taken into account. The constant progress of computer tools and digital codes makes it possible today to use this tool for the underground works project, with the computing times becoming shorter and shorter [12].

However, the two-dimensional modeling approach, for its speed and relative simplicity, is still the most widespread in the common practice of tunnel project calculations. Among the different possibilities of $2 \mathrm{D}$ modeling, the two-dimensional analysis in cross-section and plane deformations is the one most often used. In the context of this type of 2D modeling, different methods have been studied to simulate the three-dimensional effects of tunnel advancement (convergence-containment method, GAP method, soil softening method, and so on).

The other method for stability analysis is the Shear Strength Reduction (SSR-FEM). This method was applied to slope stability analysis in two-dimensional situations as well as in three-dimensional ones. It was used by reducing the shear strength parameters in the weakest surface, and then a value of the reduction for this parameter was obtained, which is defined as a safety factor. In SSR-FEM, the factor of safety was defined as the equation (10)

$$
F=\frac{\tan \varnothing \text { real }}{\tan \varnothing \min }=\frac{\text { Creal }}{C \min }
$$

where $c$ is the cohesion of the soil, and $\varnothing$ is the angle of the internal friction of the soil; $\mathrm{cmin}$ and $\tan \varnothing$ min are minimum values as needed for equilibrium.
These values were obtained by reducing the real shear strength parameters stepwise down to a failure in an elastoplastic FE-analysis.

The calculation was done by two methods, 'Staged construction' and 'Phi-c reduction'. Staged construction is the powerful Plaxis feature that enables a realistic simulation of construction and excavation processes by activating and deactivating clusters of elements, application of loads, changing of water tables, etc. This procedure allows for a realistic assessment of stresses and displacements as caused, for example, by the excavation of the tunnel. A safety analysis in the Plaxis 3D Tunnel program can be executed by reducing the strength parameters of the soil. When performing a safety analysis using Phi-c reduction, no loads can be increased simultaneously. This option is before a separate loading type that can be selected from the loading input box.

When using Phi-c reduction in combination with advanced soil models, these models will behave as a standard Mohr-Coulomb model, since stress-dependent stiffness behavior and hardening effects were excluded from the analysis.

Case Study. The studied section is a $120 \mathrm{~m}$ long part with an external diameter of $10.20 \mathrm{~m}$; the top ground layer is a superficial recent limono-clay fill layer, mixed with gravel 1.5 to $2 \mathrm{~m}$ thick.

Underlain by three major layers, clay, marl and sand (Fig. 2), the study area is excavated in the sand and marl formations, characterized by light clayey yellow sand with alternating fine to coarse pebbles with sandstone passage, the level of the ground water table is $41 \mathrm{~m}$. Table 2 represents the different soil parameters along the study area, these data were obtained from geotechnical surveys and laboratory test results from reports of the company INGEO INTERNATIONAL group of Algeria, according to Euro code standards.

Two-Dimensional finite element method. $2 \mathrm{D}$ block mesh using a 6-nodded triangular element was modeled with a plane

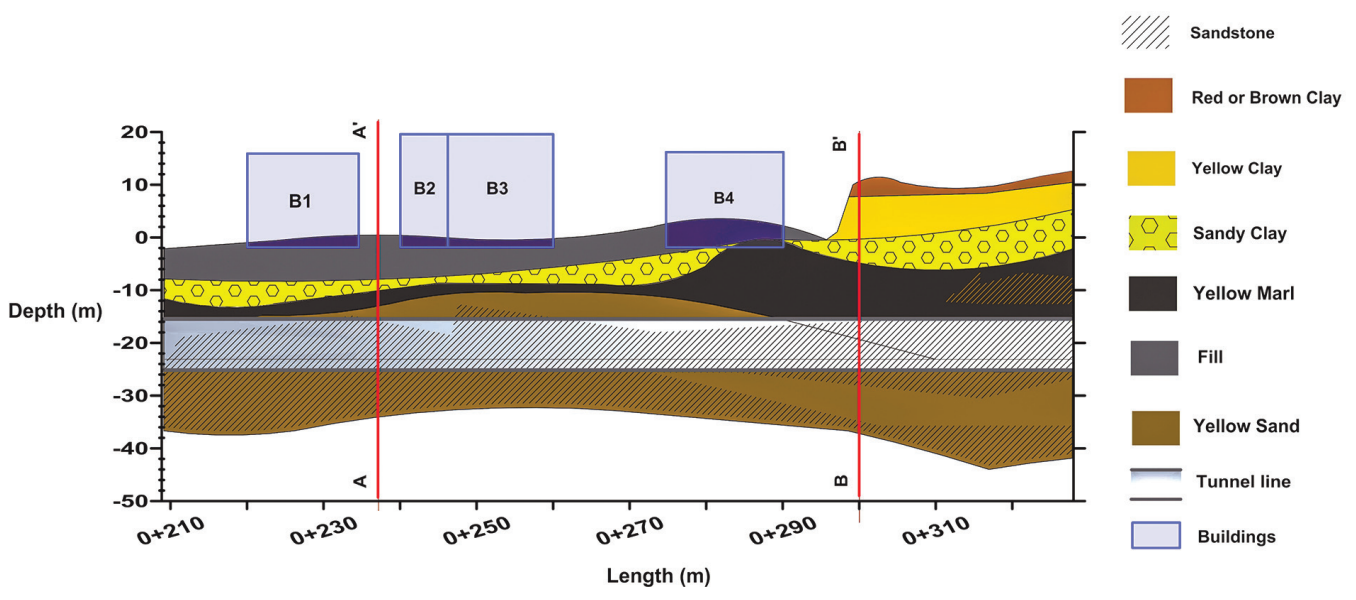

Fig. 2. Geological section of tunnel alignment

Structural parameters for the tunnel primary support

\begin{tabular}{|l|c|c|c|c|c|c|}
\hline \multirow{2}{*}{ Soil type } & \multirow{2}{*}{ thickness } & \multicolumn{5}{c|}{ Soil characteristics } \\
\cline { 3 - 8 } & & $\gamma\left(\mathrm{KN} / \mathrm{m}^{3}\right)$ & $N$ & $\phi\left(^{\circ}\right)$ & $C(\mathrm{KPa})$ & $E\left(\mathrm{MN} / \mathrm{m}^{2}\right)$ \\
\hline Fill & $1.5-2$ & 19 & 0.3 & 28 & 5 & 6 \\
\hline Yellow Clay & 8 & 20 & 0.3 & 26 & 30 & 20 \\
\hline Sandy Clay & 4 & 21 & 0.35 & 32 & 10 & 33 \\
\hline Yellow Marl & 8.8 & 20.8 & 0.33 & 25 & 40 & 35 \\
\hline Marl with Sandstone passages & 4.85 & 21 & 0.33 & 27 & 15 & 40 \\
\hline Yellow Sand with Sandstone passages & 5 & 21 & 0.33 & 27 & 15 & 40 \\
\hline Yellow Sand & 12.5 & 22 & 0.33 & 35 & 10 & 40 \\
\hline
\end{tabular}


strain model (Fig. 3). The block dimensions are of a width of $40 \mathrm{~m}$ and a depth of $27.5 \mathrm{~m}$.

Three-Dimensional finite element method. Fig. 4 shows a three-dimensional mesh block modeled with an axi-symitrical model discretized using a 15-nodes wedge element. This block has a length of $30 \mathrm{~m}$, a width of $30 \mathrm{~m}$ and a height of $27.5 \mathrm{~m}$, and was used for the analysis of face stability for the considered case study. This model size is sufficient for analyzing face stability without the concern of boundary conditions. The depth of the model was ended into a very stiff layer. The soil parameters of the model, drained ground behavior with the MohrCoulomb (MC) Model, were listed in Table 2. The MC-Model was used because the influence is only coming from the strength parameters of the soil without stiffness parameters that concern ground deformation.
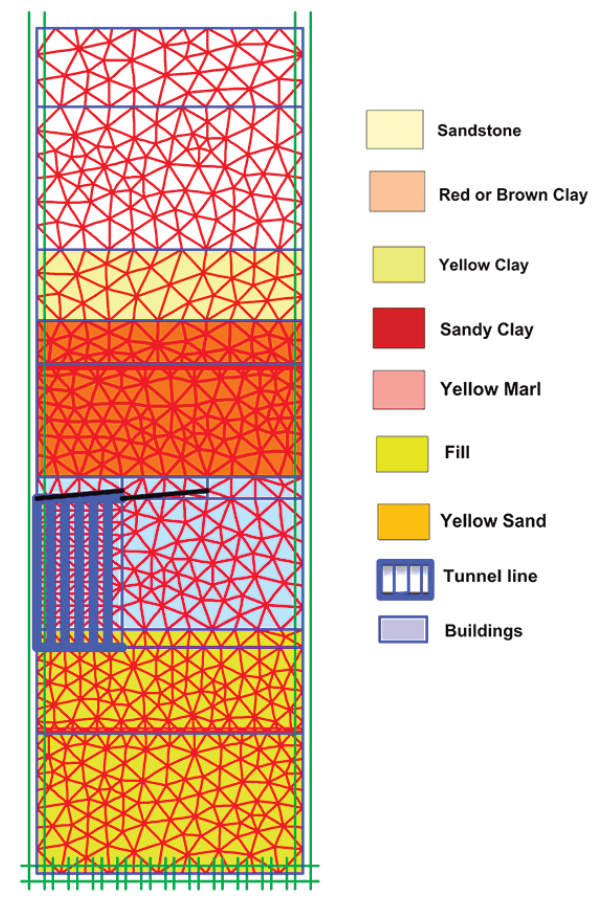

Fig. 3. 2D mesh model

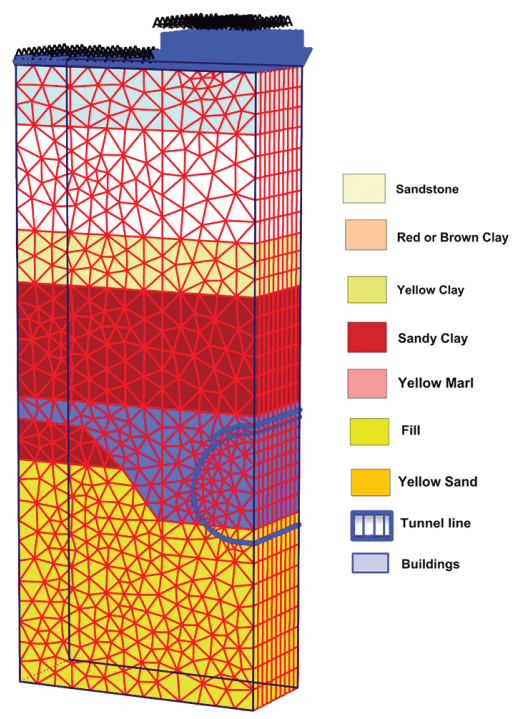

Fig. 4. 3D mesh model
Results. The results of the two methods 'Staged construction' or the plastic analysis and Phi-c reduction method are discussed as follow.

2D FE-Modelling of Face Stability. The calculation of the minimum support pressure using plastic analysis gives at the failure a value of 0.498 as a factor of minimum support pressure. The average minimum support pressure is equal to $165.68 \mathrm{kN} / \mathrm{m}^{2}$. This value is slightly more than the analytical result.

Fig. 5 shows the total displacement when face failure occurred. The figure shows more widespread deformation, when comparing with $3 \mathrm{D}$ analysis,

By using the 2D Phi-c reduction analysis method, the factor of safety from the analysis is about 11.38. Fig. 6 shows the total displacement of the deformed mesh when the tunnel face collapsed. Again, the wedge shape failure appears in the figure, and the width of the deformed zone is less than that appeared in the 2D plastic analysis. The disturbed zone is fully transferred to the surface.

3D FE-Modelling of Face Stability. In 3D FE-modelling, the factor of minimum support pressure of the applied pressure is about 0.546 from the plastic analysis. This leads to the average value of minimum support pressure of $162.15 \mathrm{kN} / \mathrm{m}^{2}$, and this

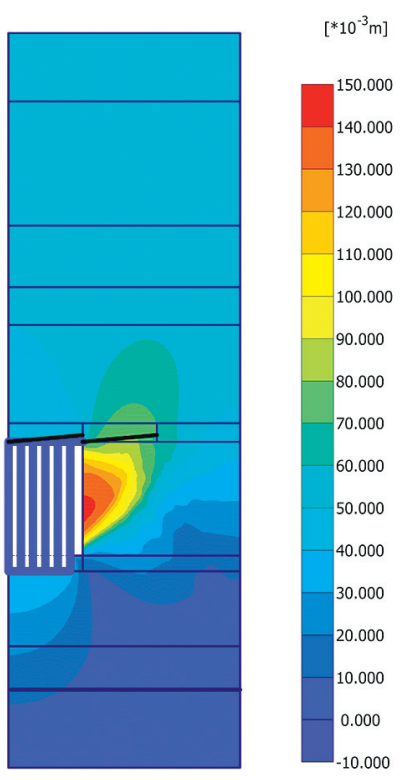

Fig. 5. Total displacements (2D plastic analysis model)

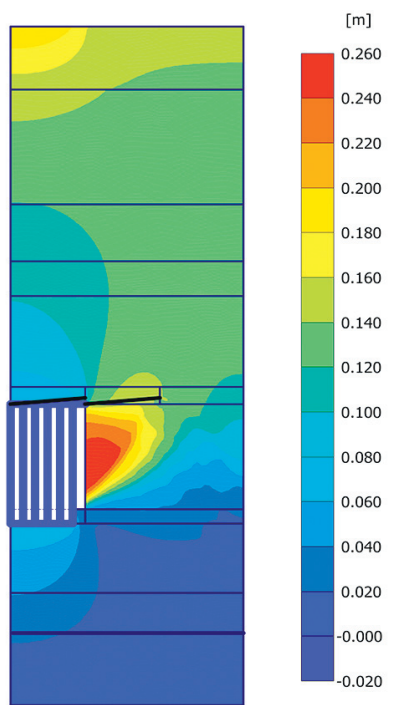

Fig. 6. Total displacements (2D Phi/c reduction model) 
result closely agrees with the results of the centrifugal test, which is equal to $163.0 \mathrm{kN} / \mathrm{m}^{2}$. The difference is minus $1 \%$. Fig. 7 shows the total displacement of 3D mesh at failure in plastic analysis; it is obvious that the deformed zone of the soil did not reach the ground surface because of the soil arching effect.

From the Phi-c reduction method, the safety factor for the failure of the model is 12.83 , which is a very high value. Fig. 8 shows the total displacement of tunnel face failure and Fig. 9 shows their direction, both figures show the formation of the soil silo. In front of the tunnel head, the wedge failure mode has appeared.

The safety factor from the plastic analysis is about 1.43 while in Phi-c reduction analysis it is about 12.83 . The huge difference between these values is due to the reason that in the Phi-c reduction method, a full soil silo was reaching the surface. In addition, the maximum displacement was about $0.12 \mathrm{~m}$ in the phi-c reduction model, while in the plastic analysis it was about $0.026 \mathrm{~m}$.

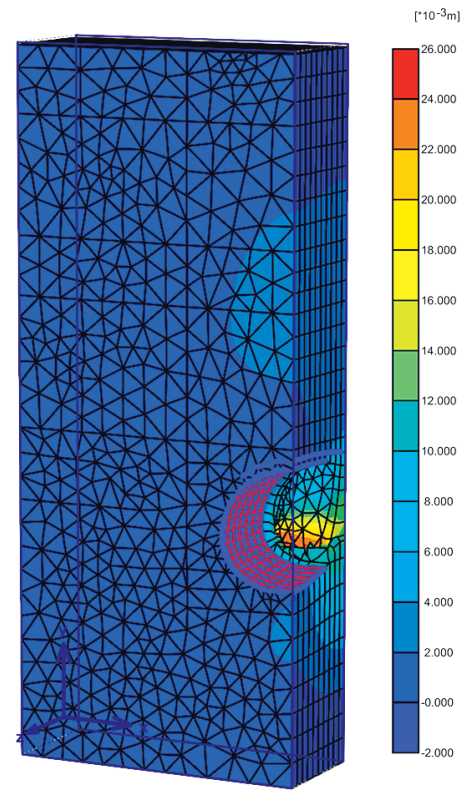

Fig. 7. Total displacement values in the 3D plastic analysis

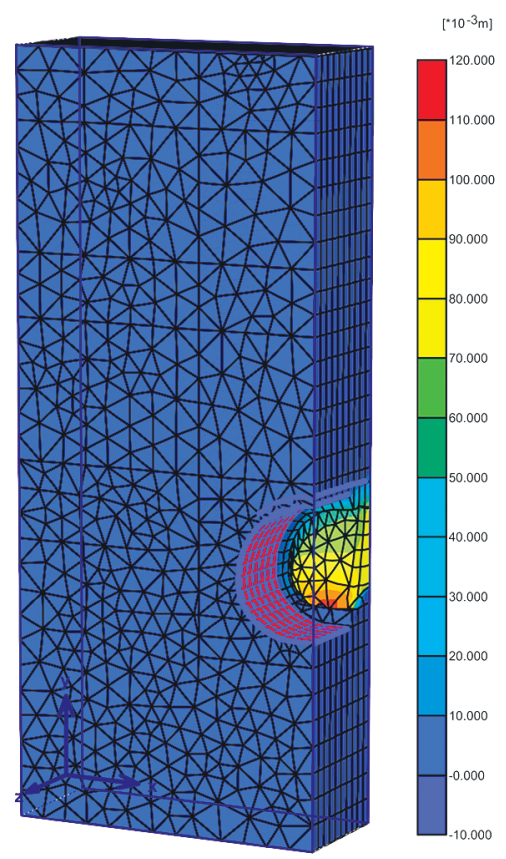

Fig. 8. Total displacement values in the 3D Phi reduction model

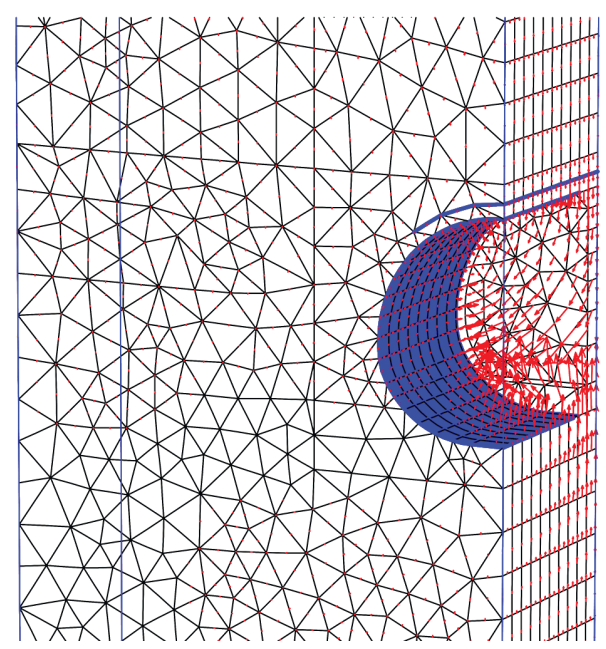

Fig. 9. Displacement direction in the 3D Phi reduction model

The higher value is explained with the non-consideration of the support system in Phi-c reduction method, this displacement decreases with the application of the support system adequate to the tunnel. The plastic analysis method is more accurate in this case and its results are more valid.

The factor of safety from the 2D Phi-c reduction method is less than the one obtained from 3D. It is about a half. A wider disturbed zone does not appear in the 2D safety analysis as the one appearing in the $3 \mathrm{D}$ plastic analysis.

Due to the effect of the missing third dimension, the disturbed zone became wider, the size of the wedge in the 2D plastic analysis is bigger than for $3 \mathrm{D}$ plastic analysis, and the rate of displacement is higher. When in 3D analysis, the curved shape on top of the silo shows the arch effect and, the wedge shape failure in front of the face appeared.

The difference between the time of calculation for $3 \mathrm{D}$ and 2D FEM for face stability was found to be not outside the practical time as in the ground deformation analysis [13].

Analytical tunnel face stability analysis. Maximum plastic deformation occurred at the bottom of the excavation face and the face stability index $(N)$ is equal to 6 when the pressure $\left(\sigma_{t}\right)$ is $165.68 \mathrm{kN} / \mathrm{m}^{2}$ in the 2D model.

While in 3D staged construction model the pressure is greater than or equal to $162.15 \mathrm{kN} / \mathrm{m}^{2}$, the face stability index $(N)$ is 5.3 , and the plastic strain at the front of the shield is greater than 1 with a pressure of $163.0 \mathrm{kN} / \mathrm{m}^{2}$.

When the pressure is less than or equal to $161.18 \mathrm{kN} / \mathrm{m}^{2}$, the index $(N)$ is 7.34 and the plastic deformation is larger than that at $162.15 \mathrm{kN} / \mathrm{m}^{2}$ in the Phi-c reduction model.

Conclusions. The result of 3D plastic calculation matched well with the analytical result, and the difference was found to be about $1 \%$. While in the result of the 2D plastic analysis, the difference from the analytical result was found to be about $4 \%$. In the plastic analysis, the 3D FE-modelling gave more accurate results than the 2D FE-modelling, and this is because the $3 \mathrm{D}$ arching effect in the $3 \mathrm{D}$ model gives a better prediction than the 2D model. The 2D results do not allow an entirely accurate analysis, even that the results obtained by the proposed 2D finite element model have a good agreement with the field data. From this point of view, the employing of threedimensional (3D) software is more desirable to design.

The SSR-FE analysis gave a higher value of the safety factor compared to the one deduced from the plastic analysis. This is because, in the SSR-FEM analysis, the safety factor is obtained from the failure mode when the soil collapse reached the surface. This showed that SSR-FEM is not applicable to the tunnel heading stability problems and it might be more useful in slope stability problems.

The analysis of the face stability index $(N)$ results show that the tunnel face stability is assured better during the Phi-c 
reduction phase than at the staged construction phase, and this is confirmed with the values of the factor $(N)$. This can be explained by the disturbance of the stress field around the tunnel during the digging process that affects the distribution of the dynamic loads of the ground, which remodel after the end of the construction phase to give a good front stability.

\section{References}

1. Elmanan, A. M.A., \& Elarabi, H. (2016). Analytical and numerical analysis for tunnel heading stability. Conference $p a-$ per: The Seventh Graduate Studies and Scientific Research Conference, Khartoum, Sudan. Retrieved from https://www.researchgate.net/publication/299377004_ANALYTICAL AND_NUMERICAL_ANALYSIS_FOR_TUNNEL_ HEADING_STABILITY.

2. Ahmed, S. N.A., \& David, N.C. (2019). Numerical modelling of tunnel face stability in homogeneous and layered soft ground. Tunnelling and Underground Space Technology, 94. https://doi.org/10.1016/j.tust.2019.103096.

3. Riaz, A., Jamil, S. M., Asif, M., \& Akhtar, K. (2016). Tunnel support design by comparison of empirical and finite element analysis of the Nahakki tunnel in Mohmand agency, Pakistan. Studia Geotechnica et Mechanica, 38, 75-84. https:// doi.org/10.1515/sgem-2016-0008.

4. Zizka, Z., Kube, S., Schößer, B., \& Thewes, M. (2020). Influence of stagnation gradient for face support calculation in Slurry Shield Tunnelling. Geomechanics and Tunnelling, 13, 372-381. https://doi:10.1002/geot.202000009.

5. Leca, E., \& Dormieux, L. (2015). Upper and lower bound solutions for the face stability of shallow circular tunnels in frictional material. Géotechnique, 40(4), 58-606. https://doi. org/10.1680/geot.1990.40.4.581.

6. Li, L., Zheng, W., \& Wang, Y. (2018). Prediction of Moment Redistribution in Statically Indeterminate Reinforced Concrete Structures Using Artificial Neural Network and Support Vector Regression. Applied Sciences, 9(28). https:// doi.org/10.3390/app9010028.

7. Fu, Y., \& Zheng, H. (2017). Numerical Research on Face Stability of Pipe Jacking Tunnel in Soft Clay. Chinese Journal of Underground Space and Engineering. Retrieved from https:// en.cnki.com.cn/Article_en/CJFDTotal-BASE2017S2020. $\underline{\text { htm. }}$.

8. Padua-Fernández, R., Rivera-Constantino, R., \& Marengo-Mogollón, H. (2011). Diseño geotécnico del túnel de desfogue del proyecto hidroeléctrico La Yesca, México. Conference proceedings, Pan-Am CGS Geotechnical Conference: $64^{\text {th }}$ Canadian Geotechnical Conference and $14^{\text {th }}$ Pan-American Conference on Soil Mechanics and Geotechnical Engineering, Toronto, Ontario, Canada. Retrieved from https://docplayer. es/21790193-Diseno-geotecnico-del-tunel-de-desfogue-delproyecto-hidroelectrico-la-yesca-mexico.html.

9. Brinkgreve, R.B.J. (Ed.) (2018). PLAXIS 2D Manuals. General Information, Tutorial Manual, Reference Manual, Material Models Manual, Scientific Manual. Delft University of Technology \& PLAXIS. ISBN-13: 978-90-76016-24-5. Retrieved from www.plaxis.com.

10. Smith, I. M., Griffiths, D. V., \& Margetts, L. (2014). Programming the finite element method ( $5^{\text {th }}$ ed.). Chichester: John Wiley \& Sons Ltd. Retrieved from https://books.google. $\mathrm{dz} /$ books? id=ZbtiAAAAQBAJ\&printsec $=$ frontcover $\& \mathrm{hl}=$ fr. 11. Barla, G. (2016). Full-face excavation of large tunnels in difficult conditions. Journal of Rock Mechanics and Geotechnical Engineering, 8, 294-303. https://doi.org/10.1016/j.jrmge.2015.12.003.

12. Janin, J.-P. (2012). Tunnels en milieu urbain: Prévisions des tassements avec prise en compte des effets des pré-soutènements (renforcement du front de taille et voûte-parapluie). INSA de Lyon, France. Retrieved from http://theses.insa-lyon. fr/publication/2012ISAL0038/these.pdf.

13. Elmanan, A. M. (2016). Elementary and Finite Element Methods for Analysis of Closed Face Tunnels (Unpublished master's thesis). University of Khartoum Suden. Retrieved from http://onlinejournals.uofk.edu/index.php/JBRR/article/view/1463/1476.

\section{Аналіз стійкості вибою неглибоких тунелів з використанням методу скінчених елементів}

\author{
I. Кахоул ${ }^{1}$, С. Яхьяоуі ${ }^{2}$, Ю. Мехіді ${ }^{3}$, Ю.Хадрi ${ }^{1}$ \\ 1 - Університет Баджі Мохтар, м. Аннаба, Алжир, e-mail: \\ ines_k19@hotmail.com \\ 2 - Національна політехнічна школа, м. Алжир, Алжир \\ 3 - Університет Ларбі Тебессі, м. Тебесса, Алжир
}

Мета. Робота спрямована на вивчення стійкості вибою тунелю (тунель метро Алжиру) та оцінку загальноприйнятих чисельних методів, що використовуються для аналізу стійкості вибою тунелю. Двовимірне (2D) і тривимірне (3D) моделювання методом кінцевих елементів (KE) з використанням програм PLAXIS.

Методика. Прокладка тунелів виконується методом NATM (Новий австрійський метод проходки тунелів); використовуються два типи розрахунків. Перший виконується шляхом зменшення тиску, прикладеного до вибою, до тих пір, поки вибій не зруйнується. Другий підхід полягає у використанні методу зменшення характеристик Phi-c (кута внутрішнього тертя та зчеплення), що заснований на розрахунку коефіцієнта безпеки при оцінці міцності грунту на зрушення. Обидва підходи застосовуються для 2D i 3D моделювання методом кінцевих елементів.

Результати. Встановлено, що визначення руйнівного тиску на вибій є важливим моментом, що дозволяє уникнути руйнування вибою або надмірних деформацій, при цьому використання чисельної процедури призводить до більш точних результатів, ніж аналітичні методи.

Наукова новизна. Полягає у використанні двовимірного та тривимірного моделювання в поєднанні із двома підходами: розрахунку конструкції із пластичних станів і методу зменшення Phi-c, заснованого на розрахунку коефіцієнта безпеки при оцінці міцності грунту на зрушення.

Практична значимість. Дане дослідження показує, що метод зменшення опору зрушенню набагато краще, ніж метод зменшення тиску на вибій. Більш того, результат 3D моделювання методом кінцевих елементів дає кращий прогноз у порівнянні з результатами 2D моделювання методом кінцевих елементів.

Ключові слова: тунель, чисельне моделювання, стійкість вибою тунелю, Plaxis 2D, Plaxis 3D tunnel, тунель метро Алжсиру

\section{Анализ устойчивости забоя неглубоких туннелей с использованием метода конечных элементов}

\section{И. Кахоул ${ }^{1}$, С. Яхьяоуи ${ }^{2}$, Ю. Мехиди ${ }^{3}$ Ю. Хадри}

1 - Университет Баджи Мохтар, г. Аннаба, Алжир, e-mail: ines_k19@hotmail.com

2 - Национальная политехническая школа, г. Алжир, Алжир

3 - Университет Ларби Тебесси, г. Тебесса, Алжир

Цель. Работа направлена на изучение устойчивости забоя туннеля (туннель метро Алжира) и оценку общепринятых численных методов, которые используются для анализа устойчивости забоя туннеля. Двухмерное (2D) и трехмерное (3D) моделирование методом конеч- 
ных элементов (КЭ) с использованием программ PLAXIS.

Методика. Прокладка туннелей выполняется методом NATM (Новый австрийский метод проходки туннелей); используются два типа расчетов. Первый выполняется путем уменьшения давления, приложенного к забою, до тех пор, пока забой не разрушится. Второй подход заключается в использовании метода уменьшения характеристик Phi-c (угла внутреннего трения и сцепления), который основан на расчете коэффициента безопасности при оценке прочности грунта на сдвиг. Оба подхода применяются для 2D и $3 \mathrm{D}$ моделирования методом конечных элементов.

Результаты. Установлено, что определение разрушающего давления на забой является важным моментом, позволяющим избежать разрушения забоя или чрезмерных деформаций, при этом использование численной процедуры приводит к более точным результатам, чем аналитические методы.
Научная новизна. Заключается в использовании двумерного и трехмерного моделирования в сочетании с двумя подходами: расчёта конструкции по пластическим состояниям и метода уменьшения Phi-c, основанного на расчете коэффициента безопасности при оценке прочности грунта на сдвиг.

Практическая значимость. Данное исследование показывает, что метод уменьшения сопротивления сдвигу намного лучше, чем метод уменьшения давления на забой. Более того, результат $3 \mathrm{D}$ моделирования методом конечных элементов дает лучший прогноз по сравнению с результатами 2D моделирования методом конечных элементов.

Ключевые слова: туннель, численное моделирование, yстойчивость забоя туннеля, Plaxis 2D, Plaxis 3D tunnel, туннель метро Алжира

Recommended for publication by Prof. M. Laid Boukeloul. The manuscript was submitted 27.08.20. 